\title{
USING PARTICIPATORY METHODS TO DEVELOP AND IMPLEMENT RESEARCH ON HISTORICAL COMPULSORY SOCIAL MEASURES AND PLACEMENTS IN SWITZERLAND
}

\author{
Patricia Lannen, Clara Bombach, and Oskar G. Jenni
}

\begin{abstract}
Many of the child welfare policies and practices in Switzerland before the law reform of 1981 were rather invasive and were exercised under a legal context that sometimes threatened basic human rights. The inclusion of survivors of such measures in the research process has been vigorously requested in Switzerland. Therefore, four individuals who had been placed in institutions as children have been included in the process of preparing a recently initiated, 60year follow-up study of individuals placed in infant care institutions in Switzerland in the late 1950s and early 1960s. Using focus interviews and "thinkaloud" methods, the interviewees commented on two parts of the planned research process: (a) how to contact the cohort, and (b) finalising the assessment instruments. Data were analysed using qualitative content analysis. Interviewees felt their participation was a sign of recognition of their experience and expertise. Their input contributed to the research in a host of ways. For example, they helped to make documents more understandable, identified errors and redundancies, and pointed out wording that might cause insecurities or negative reactions. They also pointed to shortcomings in some of the items used in the assessment instruments. In addition, they made significant contributions regarding how best to approach and work with the cohort. This study shows that, when researching historical compulsory social measures, the inclusion of formerly institutionalised individuals in development and implementation is not only feasible, but is of significant benefit to the quality of the research.
\end{abstract}

Keywords: participatory research, institutional care, infant care, compulsory social measures

Patricia Lannen $\mathrm{PhD}$ is Deputy Director and Head of Research at the Marie Meierhofer Children's Institute, Kulturpark Zürich West, Pfingstweidstrasse 16, 8005 Zurich, Switzerland. Email: lannen@mmi.ch

Clara Bombach MA (corresponding author) is a Research Associate at the Marie Meierhofer Children's Institute, Kulturpark Zürich West, Pfingstweidstrasse 16, 8005 Zurich, Switzerland. Email: bombach@mmi.ch

Oskar G. Jenni MD is Director of the Child Development Center at the University Children's Hospital Zurich and Professor for Developmental Pediatrics at the University of Zurich, Rämistrasse 71, 8006 Zurich, Switzerland. Email: oskar.jenni@kispi.uzh.ch 
Before the law reform of 1981, many of the child welfare policies and practices in Switzerland were rather invasive and were exercised under a legal context that sometimes threatened basic human rights ${ }^{1}$ (Hauss et al., 2018). Formally, these practices were referred to as "Compulsory Social Measures and Placements". They included a host of measures such as placements in care institutions and foster families on farms (Verdingkinder [contract children]), or committing individuals to psychiatric hospitals, medication trials, forced castrations, or forced adoptions. These measures served to intervene in family and personal circumstances that, from the point of view of the authorities, were "liederlich" [slovenly] or "verwahrlost" [bedraggled] and should be "disciplined" (Lengwiler \& Praz, 2018; Ramsauer, 2000; Unabhängige Expertenkommission, 2019). Even though the survivors ${ }^{2}$ of the Compulsory Social Measures and Placements have been calling attention to their often difficult experiences, historically, they have only rarely been able to make their voices heard.

We will outline the perspectives of survivors of the Compulsory Social Measures and Placements in Switzerland from the early 20th century to the 2010s, and also describe the historical and scientific reappraisal efforts undertaken since 2013. The purpose is not to document the full history, but to illustrate, with some examples, how Swiss society has dealt with the concerns of survivors over time. In particular, we will also highlight the emerging voices of survivors who have requested inclusion in research efforts into the Compulsory Social Measures and Placements in Switzerland.

\section{A Century of Trying and Failing To Be Heard}

In 1897, the 17-year-old Carl Albert Loosli, who had been living in a child and youth home in Switzerland since the age of 12 , stole 50 centimes $^{3}$ from a store. As a consequence he was given psychiatric treatment and sent to the Trachselwald Forced Education Institution, a state "rescue centre for malicious young people" (Schoch, 1989, p. 91). In 1924, as a 44-year-old writer and journalist, Loosli published a pamphlet entitled Anstaltsleben [Life in an Institution]. A year later, he released his book Ich schweige nicht! [I will not remain silent!]. In these tracts, he brought forward several reform proposals which were largely received condescendingly and rejected by educational institutions. ${ }^{4}$

\footnotetext{
${ }^{1}$ The Swiss Civil Code, introduced in 1912, allowed access to "conduct that is assessed as deviating from the norm" and granted authorities considerable leeway in their interpretation and justification of the removal and placement of a person (Seglias 2018, p. 23). In 1981, this law was amended, thus fulfilling an important requirement of the United Nations Convention on Human Rights (Seglias, 2018, p. 31).

${ }^{2}$ In German, individuals affected by such measures are referred to as Betroffene (literally, "those affected by such measures"). We have opted to translate the term as "survivors", a more common way of referring to such individuals in the English language (see, e.g., Sinclair, 2007).

${ }^{3}$ As of 2019, approximately 0.47 Euro, or 0.51 USD.

${ }^{4}$ For more on the articulation and publications of individual survivors in the 20th century, see Ammann et al. (2019, p. 8), and Unabhängige Expertenkommission (2019).
} 
International Journal of Child, Youth and Family Studies (2020) 11(4): 96-120

In 1944, the magazine Die Nation [The Nation] published a report with pictures of the Sonnenberg reformatory in Kriens that revealed the problematic conditions of residential institutions. For a short period of time, the professional world talked of an "institutional crisis", but public attention to the conditions of remanded children in Switzerland soon waned again.

In the late 1950s and early 1960s, psychiatrist Dr. Marie Meierhofer, the City Physician of Zurich, examined over 400 infants in 12 orphanages in Zurich. Her dissertation on the well-being of institutonalised infants included numerous photographs; she subsequently produced a documentary film about her research, which attracted attention far beyond the borders of Switzerland. The film, whose release followed some of the groundbreaking research on attachment and the effects of deprivation by pioneers such as John Bowlby (1951) and René Spitz (1945), showed the impacts of deprivation on children's behavior. Meierhofer succeeded in drawing attention to the problematic situation in Swiss institutions and its negative effects on children's well-being and development. Her work contributed to a nascent Swiss movement in which the conditions of care institutions were questioned as systemic and not merely isolated cases of institutional malfeasance (Bombach et al., 2018; Schoch, 1989).

In the early 1970s, the journal Der Beobachter [The Observer] published statements by Roma mothers who reported that their children had been taken away against their will. Galle (2016) authored a comprehensive historical reappraisal of the Hilfswerk für die Kinder der Landstrasse [Relief organisation for rural children], which was a project of the Swiss foundation Pro Juventute, under whose auspices these children had been removed from their homes. She showed that, although Der Beobachter prides itself to this day on having uncovered a scandal in Switzerland with their report in the 1970s, the mothers of the abducted children had tried to draw attention to their fate as far back as the 1940s. They had contacted the media at the time, including Der Beobachter, but were not given a hearing (Galle, 2016, pp. 16-18). It was not until the 1970s that "perceptions arose of the measures as scandalous, closely linked to societal changes, in particular increasing criticism of institutions that grew out of debates over reform of Switzerland's prison system at the end of the 1960s" (Galle, 2016., p. 17). Until 1981, however, the legislation related to care measures remained intact: "It allowed the authorities to withdraw individuals from their freedom, without them having committed a crime" (Unabhängige Expertenkommission, 2019, p. 35).

In the 2000s, more and more survivors turned to the public and raised their voices in the media (Seglias, 2018, pp. 26-27; Ziegler et al., 2018, p. 19). The voices of survivor-led organisations became louder: artists, authors, and journalists addressed individual stories in movies, memorials, exhibitions, autobiographies, and portraits in magazines (Botschaft Zur Volksinitiative, 2015, pp. 106-107; Seglias, 2018, p. 27). As recently as 2004, despite welldocumented problems related to institutional care, the Swiss parliament "refused to allow scientific research into the placement of children and young people, and did not agree to an already drafted federal law on the rehabilitation of forced sterilisation" (Seglias 2018, p. 27). 
International Journal of Child, Youth and Family Studies (2020) 11(4): 96-120

\section{The Swiss Reappraisal Since 2013: Listen, Look, and Slowly Become Active}

In 2013, Federal Councillor ${ }^{5}$ Simonetta Sommaruga, Head of the Swiss Federal Department of Justice and Police, initiated the movement towards a comprehensive reappraisal of the history of Compulsory Social Measures and Placements in Switzerland. She criticised the long period of looking away from reported abuse in Switzerland and demanded a historical reappraisal: "We all need to know what happened to the 'Verdingkinder' ('contract children') and other victims of coercive care measures in Switzerland" (Sommaruga, 2013, p. 2). She "wholeheartedly apologized" on behalf of the government, the first Swiss public official to ever make this kind of public declaration (Sommaruga, 2013, p. 3).

Although Sommaruga's 2013 declaration was welcomed more openly than ever before, it reflected the delay in public engagement with the darkness of the Swiss history of coercive measures in comparison with other European countries (Businger \& Ramsauer, 2019, p. 10). Between 2013 and 2018, the so-called "Swiss Round Table on Compulsory Social Measures" brought different groups together to exchange views and discuss how the demands of various stakeholder groups could be taken into account and included in the rehabilitation of survivors. The Round Table adopted a catalogue of measures. One tenet was that scientifically investigating the past was "indispensable" and should contribute to an understanding of how the measures were developed and how they affected survivors. Furthermore, the involvement of survivors in the research was called for, including interviews with contemporary witnesses (Businger \& Ramsauer, 2019, p. 42). In 2014, a survivor named Guido Fluri launched the "Reparation Initiative", which, along with other initiatives, led to new legislation.

\section{Swiss Federal Act on the Reappraisal of Compulsory Social Measures and Placements before 1981}

In 2017, the Swiss Federal Act on the Reappraisal of Compulsory Social Measures and Placements before 1981 (Bundesgesetz Über Die Aufarbeitung Der Fürsorgerischen Zwangsmassnahmen Und Fremdplatzierungen Vor 1981 (AFZFG), 2017; hereinafter referred to by the German acronym AFZFG) came into force. A reparation payment of 25,000 Swiss francs, known as a "solidarity contribution", could be claimed by formerly institutionalised people provided they could demonstrate their "victim status". Researchers investigating the biographical histories of former children in care criticised this procedure, arguing that this undue burden of proof had the potential to reactivate stigmatisation and traumatisation (Bombach et al., 2018d; Bombach et al., 2020). According to the Federal Council, the aim of the legislation was "to support victims and other affected persons in coming to terms with their own history" (Botschaft Zur Volksinitiative, 2015, p. 103).

\footnotetext{
${ }^{5}$ The Federal Council is the highest executive authority in Switzerland and comprises seven members.
} 
International Journal of Child, Youth and Family Studies (2020) 11(4): 96-120

\section{Independent Commission of Experts, Academic Research, and "The Expertise of Victims"}

The AFZFG (2017) stipulated in article 15 paragraph 1: "The Federal Council shall ensure that the Compulsory Social Measures and Placements prior to 1981 are comprehensively researched." In 2018, the 4-year mandate of the Independent Commission of Experts (ICE) on Administrative Care, appointed by the Federal Council, came to a close (Unabhängige Expertenkommission, 2019). The ICE recommended paying special attention to the perspective of survivors. In its final publications, the ICE stated: "In the opinion of the persons who were victims of coercive welfare measures and who were interviewed in the course of the ICE scientific investigation, the loss caused by the injustice suffered is immeasurable and therefore irreparable. Rather, the challenge is the rehabilitation of the people who have been excluded and stigmatized by the society and silenced by an organized system of coercion" (Unabhängige Expertenkommission [UEK] Fürsorgerische Zwangsmassnahmen, 2019, pp. 8-9).

Emerging from this 4-year study, one of the first publications of the ICE was an illustrated book that narrated individual life histories - an impressive way of giving voices and faces to people who had not been heard for a long time (Ammann et al., 2019, p. 11). A 2019 documentary film ${ }^{6}$, also produced by the ICE, included commentaries from survivors who reflected upon the importance of having the opportunity to publicly voice their experiences: the increasing public interest and sensitivity to their experiences relieved them of the burden of silence and stigma. As an outcome of its mandate, the ICE formulated several recommendations, which focused on the perspectives of survivors (Unabhängige Expertenkommission [UEK] Fürsorgerische Zwangsmassnahmen, 2019). One of these recommendations was specifically related to research:

Conducting scientific research ... with the participation of persons who were victims of coercive measures of care, i.e., with methods that are based on their experiences, grants them professional competence that can be treated on the same level as scientific expertise. This expertise of the victims should be recognised both in the production of knowledge and in compensation. (Unabhängige Expertenkommission [UEK] Fürsorgerische Zwangsmassnahmen, 2019, p. 43)

As part of the historical reappraisal in recent years of Compulsory Social Measures and Placements up to 1981, it is now finally recognised that survivors have exceptional expertise. By allowing insights into their personal fates and life histories, survivors have provided important motivation for research and have also promoted understanding for their sometimes difficult life situations (Bombach et al., 2017, 2018a, 2018b, 2020). Despite the emergent acknowledgement of their expertise, which is defined by their biographical experiences, the demands of survivors and recommendations of the ICE researchers to include survivors in research have been accepted and implemented only cautiously.

\footnotetext{
${ }^{6}$ https://www.uek-administrative-versorgungen.ch/begegnungen-projekte/film
} 
International Journal of Child, Youth and Family Studies (2020) 11(4): 96-120

While attention has been focused on the overall history of Compulsory Social Measures and Placements in Switzerland up to 1981, placement into institutions during infancy has been almost entirely ignored, even in more recent works (e.g., Akermann et al., 2014; Arnold et al., 2008; Furrer et al., 2014; Hafner, 2011; Schoch, 1989). This was not least because, unlike other groups of survivors, these men and women may not remember the events due to their young age at the time. They are historical witnesses of that time, without the ability to explicitly provide us with a historical testimony.

\section{National Research Programme "Welfare and Coercion" and the Study "Life Histories"}

In 2017, 2 years before the publication of the ICE report, the Swiss National Science Foundation (SNSF) launched the National Research Programme (NRP76) with 18 million CHF in funding for research projects under the umbrella of "Welfare and Coercion - Past, Present, Future". The NRP76 funds research that analyses "the characteristics, mechanisms and effects of Swiss welfare policy and practice in their various contexts. Possible causes for welfare practices that violate and promote integrity are to be identified and the effects on those affected investigated" 7 . This funding represents a societal-level recognition of the problematic histories of coerced welfare practices in Switzerland.

The present study received funding under this programme and is a continuation of the aforementioned work begun by Dr. Meierhofer more than 60 years ago. At that time, she studied the developmental and life circumstances of infants under the age of $3(N=421)$ institutionalised in the canton of Zurich (Meierhofer \& Keller, 1974). Between 1971 and 1973, she studied a subset $(N=150)$ of these children for a second time (Meierhofer \& Hüttenmoser, 1975). Meierhofer compared this assessment with a study of the 1954-1956 cohort of children living with families, which was undertaken by the University Children's Hospital's Zurich Longitudinal Studies (ZLS), as discussed in Wehrle et al. (in press). In 2013, researchers at the Marie Meierhofer Children's Institute conducted an interview-based study with 16 individuals of this cohort (Ryffel \& Simoni, 2016).

In the current study, we reanalyse the historical data with modern statistics and locate former study participants, now in their early 60s, to learn about how their lives have developed (Lannen et al., in press). Concurrently, the ZLS is also contacting and recruiting the individuals of their 1954-1956 cohort. This research design allows for a 60-year follow-up of individuals with different starting conditions in early life.

The inclusion of survivors in the research process has been vigorously demanded by survivors themselves (Hauss, 2018, p. 219; Seglias, 2018, pp. 30-31; Unabhängige Expertenkommission [UEK] Fürsorgerische Zwangsmassnahmen, 2019, p. 43; Wigger, 2018; Ziegler, 2018, p. 71; Ziegler et al., 2018, p. 12). While social sciences in Switzerland have by and large committed to a participatory model of research, there is still a dearth of good research

\footnotetext{
${ }^{7}$ http://www.nfp76.ch/en
} 
International Journal of Child, Youth and Family Studies (2020) 11(4): 96-120

practices to draw from when developing research methodologies and approaches designed to include survivors in research related to Compulsory Social Measures and Placements (Lengwiler, 2018, p. 175).

As part of the 60-year follow-up study, we worked with four survivors, who provided input during the preparatory stage of the project. Through this inclusion, we hope to demonstrate the opportunities and challenges of collaborating with survivors in the research process.

\section{Method}

Four survivors, one woman and three men, aged between 54 and 60, were involved at the beginning of the research activities. Three of them had been placed in care institutions as infants between 1959 and 1965, and one of them both as a toddler and as an adolescent. One person was part of the original Meierhofer study and had been in contact with the research team of the Marie Meierhofer Children's Institute since the exploratory study in 2016 (Ryffel \& Simoni, 2016). Two others were known to the research team through private contacts. Another had become involved in the reappraisal of Compulsory Social Measures and Placements in Switzerland, and had contacted various research institutions demanding to be included and heard. At the Marie Meierhofer Children's Institute this request was welcomed and the individual was invited to participate in the preparations for this study.

We would like to take this opportunity to thank them once again for their commitment to and support of the study.

Using focus interviews (Atteslander, 2010, pp. 133-134; Flick, 2014, pp. 211-212) and "think-aloud" methods (Charters, 2003, p. 68), the four interviewees contributed to the research planning process, offering suggestions on how to contact the cohort and how to finalise the assessment instruments. Focused interviews took place in a one-to-one setting, in a location chosen by the interviewee. At the explicit request of some of the interviewees, joint exchanges in a group setting did not take place.

Material was either read by the interviewee or read aloud by the researcher. Table 1 shows which "prompt materials" were presented at which interview times. The think-aloud method was applied in order "to try to see into the minds of individuals. Participants are asked to voice the words in their minds" (Charters, 2003, p. 68). Interviewees were asked to respond spontaneously to what they had just heard or read. The interviews each lasted up to 2.5 hours. The interviewees each received 100 Swiss francs plus travel expenses, and a fixed-expense allowance for participation in parts of the study (completion of the questionnaire: 80 Swiss francs; on-site health assessment: 80 Swiss francs). The study has been approved by the Ethics Committee of the University of Zurich. 
International Journal of Child, Youth and Family Studies (2020) 11(4): 96-120

Table 1. Chronology of Preparation for Focused Interviews

\begin{tabular}{|c|c|}
\hline Interview Time & Material \\
\hline $\begin{array}{l}\text { Initial contacting of the cohort } \\
\text { (Spring 2019) }\end{array}$ & $\begin{array}{l}\text { Information about the study on the Marie Meierhofer Children's Institute } \\
\text { website } \\
\text { Recruitment procedure for study participants } \\
\text { Letter } 1 \text { with response slip } \\
\text { Letter } 2 \text { with response slip } \\
\text { Informed consent documentation } \\
\text { Flyer with information on support and access to archives }\end{array}$ \\
\hline $\begin{array}{l}\text { Finalising assessment instruments } \\
\text { (Summer 2019) }\end{array}$ & $\begin{array}{l}\text { Study logo } \\
\text { Questionnaires on health and well-being; for details see Lannen et al. (in } \\
\text { press) } \\
\text { On-site health assessment (neuropsychological tests focused on cognitive } \\
\text { and motor abilities); for details see Lannen et al. (in press) }\end{array}$ \\
\hline
\end{tabular}

The interviews were audio-recorded and transcribed verbatim in Swiss German, with annotations on emotions and pauses. The interviews were analysed using qualitative content analysis (Mayring, 2015) and coded with the help of MAXQDA, a software program for analysing qualitative data. This allowed us to work with the different data sources (transcripts and emails). We used an initial inductive process to develop overall content categories. In the next step, subcategories were formed, which were used for structured content analysis and a deductive process of applying categories. Categories were then reviewed and expanded.

\section{Contacting the Cohort (Spring 2019)}

The first prompt materials (Flick, 2014, p. 213) were presented in the order shown in Table 1. In some cases, the documents were either read aloud on request or the interviewee read the documents themselves. More detailed questions followed, related to comprehensibility, clarity, irritations, and suggestions for change. This mostly resulted in an open discussion about what the text triggered in the interviewee or could trigger in another reader. As the amount of information provided by other documents increased, we referred back to earlier documents, put them into context, and discussed their differences. As soon as the detailed discussion on one document was completed, another was presented and the reading and questioning session was repeated.

\section{Finalising Assessment Tools (Summer 2019)}

The interviewees were asked to look at the questionnaire, and fill it in if they chose. The questionnaire was sent to the interviewees' homes, to create a situation similar to that of future study participants. Interviewees were then able to express their impressions of the procedure and of the content and scope of the questionnaire by telephone, by email, or on-site at the Marie Meierhofer Children's Institute. Interviewees came to the Institute to take part in neuropsychological testing; at that time, they were presented with proposed designs for a logo for this study, and their feedback was requested. 
International Journal of Child, Youth and Family Studies (2020) 11(4): 96-120

\section{Results}

The response of the formerly institutionalised individuals to being invited to participate was overwhelmingly positive. All four individuals immediately agreed to participate. When asked how they felt about being invited to participate in the study preparation phase, they said they thought it was a sign of recognition for their cause, their experience, and their expertise - a response to the request of survivors to be included in research (Unabhängige Expertenkommission [UEK] Fürsorgerische Zwangsmassnahmen, 2019). Interviewees saw themselves as skilled partners who could inform the research process: "Well, I am proud to be able to do this and I find it exciting. It's a new challenge for me and I'm really curious about what's next" (Interviewee B, Spring 2019, 8). It was crucial for all interviewees that their opinion be taken seriously and that it not be a pro forma exercise. To shape the study preparations, they put themselves in the shoes of future study participants, and drew on their own experiences.

The interviewees emphasised their conviction that research on this topic was done well and appreciated the opportunity to participate: "Well, I did insist on being included in the project in advance. And that it's also important that people like me are involved who are critical of the whole issue... It is important to me that the work is now done right." (Interviewee A, Spring 2019, 23)

\section{Wording, Formatting, and Visualisation}

The input of the interviewees contributed in a host of ways to the research undertaking. They provided a barometer of progress, indicating that we were on track and that preparations were being done diligently. In documents created to communicate with potential participants, they identified errors and redundancies as well as pointing out wording that might cause insecurities or negative reactions. For example, we discussed how best to refer to neuropsychological testing. After the interviewees raised the concern that "testing" would be associated with negative judgment, we came up with an alternative term: "on-site health assessment". The discussion about the study logo (see Figure 1) included a reflection on what particular associations and emotions might be triggered. There was a sense that some of the imagery depicted belittlement, or that images of infants suggested that no time had passed. It was important to the interviewees to recognise themselves in the study today, and they emphasised that they wanted to be reflected in the study logo as adults who have since left behind their childhood, however formative it may have been. "Quite spontaneously, I immediately decided on the version with the photos, because it shows a funny collection of fictitious photos from later life, one of them even on the smartphone, based on the loving and colored caricature of the toddler, which I find particularly contemporary and appealing. The overall presentation is more stimulating to me than the tree of life, under which the toddler still lies" (Interviewee C, Spring 2019, 3). 
Figure 1. Two Possible Versions of the Study Logo

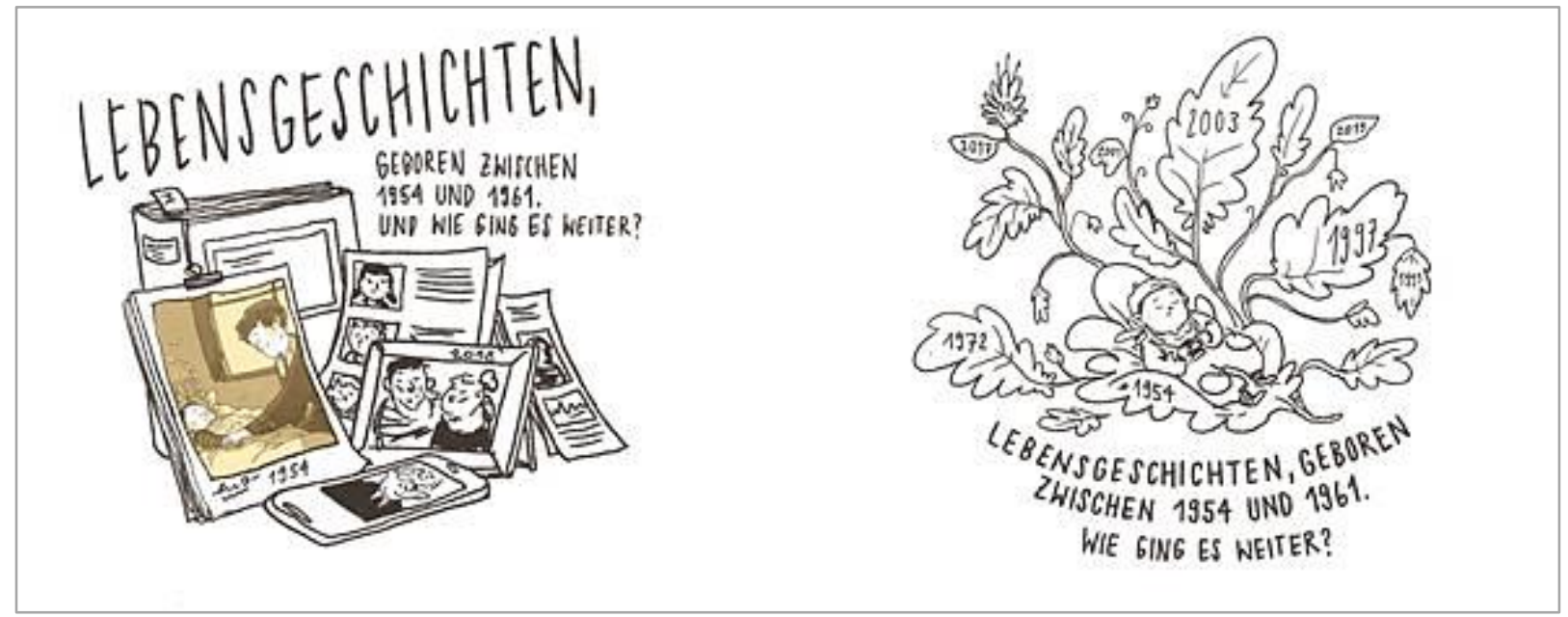

Biographical experiences were sometimes triggered through certain wording or approaches. For example, interviewees commented on the formatting and the language of the letter and thought that the initial version too closely resembled a letter from authorities. They thought that the language needed to be simplified: "I just find, the way it has been written is too complicated" (Interviewee B, Spring 2019, 714). It reminded them of some of the negative experiences they had had with authorities, who were involved in the decision to place them into the institutions. For example, remarking on the fact that the letter stated that we had found the individual's name and year of birth in the archive and were hence contacting them once again, Interviewee B stated: "Well, one might ask themselves: What is this? What kind of documents are these?" (Spring 2019, 280).

\section{Motivating the Cohort}

In addition, interviewees made significant contributions to determining how best to approach the cohort. For example, they helped shape the narrative in the invitation to participate, suggesting a shift from "Sorry to bother you" to "Here is an opportunity to remain in the study". They also suggested emphasising the chance for participants to have their voices heard as adults in a way that had not been possible when they were children:

I would probably formulate it more positively, so the motivation again: "You are already in the study anyway. And we're looking at a new time now. We'll also look at many other points in time" — something like that — "and now you just answer the questions. It's wonderful to have you back!" Something like that. (Interviewee C, Spring 2019, 203-205)

They also guided the contact process towards a balance between being assertive enough to optimise the response rate and overwhelming the participants. Interestingly, in several instances 
International Journal of Child, Youth and Family Studies (2020) 11(4): 96-120

we had taken a more careful and conservative approach than was suggested by the interviewees. For example, we suggested coding someone as a "passive decline" after three unsuccessful attempts to contact them by phone, under the assumption that they did not want to participate and that we should therefore discontinue our efforts to engage them. The interviewees insisted that we should send another note to let potential participants know that we were unable to reach them and ask them to get in touch, so that those wanting to share their views were not left out because they did not pick up the phone.

The interviewees were also helpful in guiding our attempt to communicate further details of the study: the available internal and external support systems and the different ways someone could decline participation. They thought that mentioning the availability of psychological support might be useful, but cautioned that if it were mentioned too often it might increase the sense of risk related to participating in the study. They also strongly advised against providing a leaflet with information on available support to every study participant, suggesting instead that it should only be offered when someone indicated distress: "And if you read the form now, I think the majority of people would conclude: 'I am in desperate need of psychiatric help.', (Interviewee A, Summer 2019, 43). Interviewees also provided feedback in relation to the ability to opt out at any time. They agreed that although it is important to make explicit that participants can opt out at any time, overstating it could deter some who would otherwise have been willing to participate: "Well, that's just the danger of something like ... 'Now I'm being asked to get out again. Now I'll get out.' ((laughs)) ((pause: 3 seconds)) I'd take that out" (Interviewee C, Spring 2019, 241).

\section{Including Different Perspectives}

Interviewees stressed that participants of the study would exhibit a range of ways of coping with the past, which would shape their reaction to being contacted. Interviewees stressed that the approach needed to be flexible enough to respond to these varying reactions. When reflecting on including survivors in the research process itself, they stressed the importance of including multiple individuals. Ideally, each participant's experiences and ways of dealing with their past and present would be unique, giving the research team the opportunity to reflect on a range of issues and perspectives:

I think it's a damn difficult question now. Because everyone's different again, aren't they? On the one hand, as I said, there are those who call out and demand again, but cannot say: "Hey, because of this and that we have a claim." ... And then there are those who say (speaks softly and carefully): "Oh, now we have to shut up and not say anything." And there are also those who say: "Hey, I'm not sick hey." Are they okay? Are they crazy? And then there are others who think, “Oh yes, I'd be glad." (Interviewee A, Spring 2019, 309-317) 
International Journal of Child, Youth and Family Studies (2020) 11(4): 96-120

The four interviewees also made explicit efforts during the interviews to take different perspectives themselves and consider how others would respond: "My siblings, they are also in the study, and I'm trying to put myself in their shoes and see what it would take to get them to participate" (Interviewee B, Spring 2019, 147).

Interestingly, they also acknowledged limitations when they sensed that they did not have the skills or experience to comment on a specific issue: "Yeah, I'm just not that spontaneous (laughs). You know, certain things I just can't say" (Interviewee B, Spring 2019, 207). Interviewee A addressed it even more clearly: "I cannot say anything, I am not competent. And if there's nothing to say, I think you should shut up" (Spring 2019, 143).

\section{Feedback on Data Collection}

Each interviewee expressed their personal likes and dislikes in terms of assessment method (questionnaire, on-site health assessment, or interviews), according to their own image of what these assessments comprised and what purpose they would serve: "I always find questionnaires, no matter who makes them, no matter how brilliantly they're done, I always find them wrong" (Interviewee A, Spring 2019, 159); "The tasks (in the on-site health assessment) were unexpected, with many that I didn't know, naturally, and very tricky and interesting (laughs)" (Interviewee D, Summer 2019, 8); "I would fill in the questionnaire at home and then bring it with me to the interview" (Interviewee B, Spring 2019, 90). There was scepticism in relation to the value of some of the items in the questionnaires:

I ask myself: What's the point? Now I fill out the form and now they ask me stupid questions.... Yes, just (laughs) just. One should just think about it: "Does the question really need answering or can't I put it differently?" (Interviewee A, Summer 2019, 83)

Being misunderstood was a concern: some felt it was not possible to capture what was truly going on for them using a standardised format. The interviewees did not want to go back to being "just one of many", as they had been in the institutions, where an individual's fate, development, and preferences carried little weight.

There was a tangible concern about being purposely misled or being judged by the researcher - a concern that may reach back to their institutional experiences: "For me, this is a trick question... If I were to say 'true', then they'd think I was a psycho.... I assume people won't answer truthfully” (Interviewee A, Summer 2019, 271).

The feedback also revealed more serious shortcomings and the inappropriateness of some of the items used in standardised questionnaires with this population. For example, one item referred to leisure activities and mentioned playing golf. This triggered an intense reaction in one of the interviewees. He was appalled at the assumption that someone in their situation would have the financial resources to play golf. 
International Journal of Child, Youth and Family Studies (2020) 11(4): 96-120

The responses revealed some limitations of attempting to capture what is going on in the lives of survivors through these methodologies. One interviewee referred to a questionnaire item that asked about the experience of his parent's death. He argued that evaluating the experience of a parent's death can be interpreted very differently, depending on how the relationship with the parent had been. If someone checked the box "it was a good experience", was that out of relief that the beloved parent no longer had to suffer, or that the parent, who had caused one so much suffering, was "finally gone"?

While it may not be possible to change some things in the research study, particularly when using standardised measures, the honest and direct exchange between interviewees and interviewers provided an opportunity for collaboration to find creative solutions. In the case of the concerns with data collection, possible solutions were inserting comment fields and information in the instructions emphasising to participants that there are no right or wrong answers, and no negative consequences, no matter what items in the questionnaires they check off or how they perform in the on-site health assessments.

\section{Expertise}

The use and meaning of the term "expert" was discussed extensively. The research team initially used the term "experts" to refer to the survivors providing input. While those individuals were confident that they had something significant to add to the study, they either did not recognise themselves in the term "expert" (and thought it referred to the researchers) or explicitly mentioned that they thought it was "a bit too much" (Interviewee B, Spring 2019, 66).

It became clear that the term "expert" somehow had a negative connotation and triggered memories of unequal opportunities and power. Individuals made the connection to their own biographical experiences of institutional placement by authoritarian decision-makers during early childhood and youth. These experiences are still present for them as part of the historical reappraisal process of care practices in Switzerland.

When asked what term to use instead, the importance of "empathy" in contrast to "expertise" surfaced: "I'm going to throw the term empathy into the room, empathy, that's something. Or an 'effort to be empathetic', maybe. So that we don't have to proclaim right away to have attained empathy already" (Interviewee A, Spring 2019, 93).

The question of what the statements of survivors as experts are worth monetarily, and the question of financial renumeration in general, was discussed at length, at least with one participant. This followed an initial decision of the study team to issue gift cards rather than cash for a number of practical reasons. Upon reconsideration, we issued a cash reimbursement as the participant in question had vigorously requested. He thought that gift cards were a form of heteronomy: many individuals who have experienced institutional placement live in poverty; researchers earn money (salaries) and recognition (titles, publications) from the work they do 
International Journal of Child, Youth and Family Studies (2020) 11(4): 96-120

with survivors and their hardship. There was a sense that survivors were being fobbed off with gift cards:

As I said, the money is of course important to me, but the thought of money is not in the foreground. The appreciation, you know? That... I can't have people who don't understand the story doing a study. Do you understand? I have to be honest with you. Because it's just important that people notice that. (Interviewee A, Summer 2019, 346-348)

\section{Scepticism About and Increasing Understanding of Research Activities}

All interviewees expressed the importance of transparency in relation to research intent and research process. One interviewee initially thought, for example, that we were purposely omitting information. It was only through their feedback that we realised that our wording had not been clear and that this lack of clarity had made possible a host of misinterpretations.

There were also instances where interviewees questioned researchers' skills and sometimes science in general, imparting their feeling that researchers do not and cannot understand the perspective of a survivor. A strong call to researchers' responsibilities also surfaced: interviewees emphasised the "power" researchers have to convey messages on their behalf and also emphasised how important it is that this research into the Social Compulsory Measures and Placements for the purpose of historical reappraisal be done well.

However, as the process went on, we found that the interviewees were making efforts to understand the methodological and ethical complexity of the research process: "Well, it's a hell of a situation, yeah. It's just another one of those situations where you can't do it right" (Interviewee A, Spring 2019, 388). They also expressed appreciation for the research effort: "Yes, I think it is madness that there are people who are actually devoting themselves to this research now ... who really take on this work and bring to light something that was done systematically many years ago" (Interviewee C, Spring 2019, 8).

\section{Discussion}

This study adopted a methodology that sought to include in the development and implementation of a research project the perspectives and experiences of individuals who are normally viewed as research subjects. While the research project on formerly institutionalised individuals is still ongoing, the inclusion of survivors has led to significant learnings and successes in its initial stages. Overall, the study shows significant benefits of participatory methods for the implementation of research on historical compulsory social measures and placements. 
International Journal of Child, Youth and Family Studies (2020) 11(4): 96-120

\section{Evaluation of Methods and Approach}

Overall, the methods and setting chosen worked well. On the one hand, they allowed us to concentrate on the content, the documents at hand, and our specific questions; on the other, they were flexible enough to provide space for interviewees to relate their biographical narratives. Some interviewees found it challenging to come up with thoughtful, spontaneous feedback during the interviews, but followed up with additional insights afterwards. They appreciated the iterative approach that allowed us to report to them how we had integrated their feedback from the previous round of data collection.

The approach required significant extra time and resources, which were made possible through the SNSF. The introduction of feedback loops added to the complexity of the preparation process. The interviews tended to be lengthy, especially when individual biographical experiences were triggered. It was essential to conduct the interviews patiently in a quiet setting. It also proved important that we remain available and in contact after the formal interviews.

During the focused interviews, we experienced a constant back and forth between focused input and narrations of individual stories. It became clear (once again) that triggering terms could be found in contact letters that seemed innocuous to researchers; this revealed the importance of listening. Creating space and time for individual experiences and biographically relevant topics to find their place and be heard was critical, even if the purpose of the interview was ostensibly to discuss procedural research details. We as researchers needed to be familiar with potential biographical themes in order to act as a sounding board and to express empathy and understanding.

The experiences of Compulsory Social Measures and Placements continue to affect the lives of individuals, even after many years, and need space and time for expression (Bombach et al., 2017; Bombach et al., 2018a, 2018b, 2018c). By listening to survivors, we learn of experiences that can be triggered with even our most carefully constructed questions. For example, many of those affected have had the experience of not being believed when they were children and adolescents. As Waisehüsler [those who live in an orphanage] they were labelled "chronic liars"; they described to us the suffering that arises when one is not believed. Recent research using biographical interviews describes the scepticism of interviewees who have questioned whether their statements in the interview are taken seriously (Bombach et al., 2017). Bombach et al. (2020) uncovered social scepticism, which can become entrenched over the course of a lifetime, and is marked by distrust of others, but also of oneself. Even in adulthood, survivors often would not discuss their own experiences of being placed in an institution; even with their closest friends and family, there was the fear of having to explain something for which they bore no guilt and yet continued to feel "guilty". Silence — treating the subject as taboo and not to be discussed was a path chosen by many. However, other survivors wanted to make themselves heard after a long silence in adulthood; they wanted to make the years of inner struggle visible and to accuse 
International Journal of Child, Youth and Family Studies (2020) 11(4): 96-120

those whom they felt should be held responsible for it. Cautious scepticism, restraint, frustration, and anger may be some of the emotions that confront researchers when they meet survivors and ask critical questions, whereas other survivors might express gratefulness to be heard - all of these emotions are quite justified in the light of the biographical narratives of the people affected.

\section{Participatory Research}

Contrary to researchers, who generally tend to keep their private experiences separate from their professional roles, survivors generally do not make such a distinction. In the framing of our research, this turned out to be an asset.

We are aware that with this form of involvement of survivors in the research process we are only beginning down the path towards achieving the desired participation levels. Our study has only just begun and there is still a lot of work ahead of us if we are to claim to take the needs and experiences of survivors into account in the way the ICE demands (Unabhängige Expertenkommission [UEK] Fürsorgerische Zwangsmassnahmen, 2019, p. 43).

For some years now, participatory research in social sciences has been experiencing an upswing (e.g., Bergold \& Thomas, 2010; Chiapparini, 2016). However, full inclusion of survivors of Compulsory Social Measures and Placements in the research process is still rare. Many researchers regard the process of including survivors with caution, or interpret it as a sign of weakness when a researcher acknowledges being a survivor or a relative of someone who has been affected. Some argue that different perspectives cannot be included in the research process because they will blur the personal and the professional, the researcher and the researched, the subject and the object.

Successful models can be found in Canada, for example, where Indigenous researchers who have themselves been affected by similar intrusive care - such as the Sixties Scoop and residential care movement (Arsenault, 2015) - have been at the forefront of documenting the effects on survivors as part of a reconciliation process (Sinclair, 2007).

We also identified some limitations of this type of approach. One was the role we gave the interviewees: they came in as "consultants" at particular stages, and were not all equally informed about the study objectives and approach. Some were only briefed in detail on the study objectives and methodology during the interviews. Sometimes, they would challenge our expertise as researchers and our choice of methods, and suggest changes that were not possible to make, either because they would modify the core of the study (which had been funded and approved in this way), or because of the standardised nature of the instruments. Furthermore, some of the ideas and activities that the interviewees suggested were not suitable for research activities, but were more appropriate in advocacy, or peer-survivor networking. This led to the conclusion that it is important to be very explicit about the scope of everyone's role: what it entails and what it does not. 
International Journal of Child, Youth and Family Studies (2020) 11(4): 96-120

\section{Added Value to Research Projects}

Including survivors in the beginning stages of our study provided significant benefits. We got to know and appreciate the interviewees as skilled sounding boards with excellent theoretical, historical, political, and pragmatic knowledge and wisdom. Particularly noteworthy are their contributions to sharpening the narrative of how to approach the cohort: they helped us shape the narrative to convey a sense of inviting the participants to remain part of an ongoing, joint undertaking and to speak up as adults about their experiences and perspectives, given that they had been unable to do so as small children.

Overall, having the interviewees vet the approach, wording, and instruments improved our approach to the cohort and is expected to significantly increase recruitment numbers. Including survivors in the process can also provide researchers with confidence and help participants to trust them, as it attunes researcher's intentions with the needs and priorities of survivors. Further, survivors may be able to act as intermediaries since they can provide information about the study, its relevance, and its objectives to their peers.

Interviewees further challenged us to think through the risks of the study more deeply. For example, we discussed the risk of disclosing an institutional placement to a survivor who was not aware of it, due either to their age at the time or to repression of memories (Freyd, 1996). Interviewees provided input on how to minimise disruption, provide opt-out solutions, or provide just a minimum of information to allow an individual to convey that we must be mistaken in terms of their identity, while still affording those who wanted to have their voices heard an opportunity to participate in the research.

Importantly, interviewees encouraged us not to assume that all individuals are fragile. While they fully supported our cautious approach, they reiterated that individuals are generally able to take responsibility for self-protection. This is in line with statements from other research with trauma survivors: there is often the implicit assumption that survivors are not emotionally stable enough to assess risk or seek help (Black \& Black, 2007). However, evidence suggests that participants can and do decline to participate when they are concerned about becoming upset (Brabin \& Berah, 1995; Dyregrov et al., 2011; Jorm et al., 2007; Omerov et al., 2014).

While remaining sensitive to vulnerabilities and any distress the study might cause, it was crucial to see interviewees as competent and skilled, to appeal to their resources and strengths, and to foster in them a desire to share their stories. Our work with the interviewees reaffirmed the soundness of our salutogenic approach to the study. Antonovsky (1979) coined the term "salutogenesis" after observing "how people manage stress and stay well". He noticed from his studies that not all individuals experience negative health outcomes in relation to stress. Some people achieve health despite their exposure to potentially disabling stress factors, and are able to stay well despite, or maybe even thanks to, coping with illness or disability (Antonovsky, 1987). Similar findings come from the 40-year longitudinal study by Emmy Werner (2013) and have given rise to research related to resilience as a broad conceptual umbrella related to positive 
International Journal of Child, Youth and Family Studies (2020) 11(4): 96-120

patterns of adaptation in the context of adversity (Masten \& Obradović, 2006). This notion lies at the core of our way of working with this cohort. Our intention is to document life trajectories, no matter what beginning they might have had or what course they might have taken.

\section{Empathetic Experts}

While survivors intuitively engaged in both key aspects of empathy — perspective-taking and emotional literacy (Steiner \& Perry, 1999; Watt \& Panksepp, 2016) — as part of being interviewed, we as researchers learned to refocus our interaction with survivors in that way as well. The interviews helped us reflect and grasp more fully the responsibilities we have towards our research subjects. They helped us to reflect upon our roles, recognising the limits of our skills and competencies, and were an opportunity to accept critical feedback. We also learned that, in order to create lasting, meaningful collaboration, it is of paramount importance to respond to individual needs with compassion and empathy. The interviewees taught us some humility, revealing limitations to our expertise and skills and making us keenly aware how expertise from survivors complements research expertise.

On the other hand, interviewees showed growing understanding of the complexity of the decisions we as researchers had to take and an increasing appreciation of the pragmatic approaches that researchers must engage in to complete the tasks at hand.

In the end, mutual respect and understanding grew tangibly over the course of these focused interviews. Strikingly, it became clear that, for survivors, it was primarily neither their own expertise nor the expertise of the researchers that was most relevant - it was empathy. This relates to the beautiful remark by Annegret Wigger, member of the Round Table: "Recognition of past injustice ... becomes tangible for survivors if the person they share their story with actually lets themselves be touched by their suffering" (Wigger, 2018, p. 155). Instead of remaining distant and untouchable, the researcher becomes humanly approachable.

\section{Acknowledgement}

We would like to thank in particular the four survivors for their commitment to and support for the study. This project was funded through a grant from the Swiss National Research Program NRP76 "Welfare and Coercion" of the Swiss National Research Foundation (Number 407640-177293, The impact of infant institutionalisation and educational practices mid 20th century in Switzerland - a 60-year long-term follow-up study). 
International Journal of Child, Youth and Family Studies (2020) 11(4): 96-120

\section{References}

Akermann, M., Jenzer, S., Vollenweider, J., \& Meier, T. (2014). Kinderheim und Sekundarschule St. Iddazell. Historische Untersuchung: Bericht der BLG Beratungsstelle für Landesgeschichte, Zürich, zuhanden des Vereins Kloster Fischingen [St. Iddazell children's home and secondary school. Historical investigation: Report of the BLG Advisory Centre for Regional History, Zurich, for the support of the association Kloster Fischingen]. Beratungsstelle für Landesgeschichte. doi:10.5167/uzh-102008

Ammann, R., Huonker, T., \& Schmid, J. (2019). Gesichter der administrativen Versorgung: Porträts von Betroffenen (Vol. 1) [Faces of administrative care: Portraits of those affected (Vol. 1)]. Unabhängige Expertenkommission Administrative Versorgung. Chronos.

Antonovsky, A. (1979). Health, stress, and coping. Jossey-Bass.

Antonovsky, A. (1987). Unraveling the mystery of health: How people manage stress and stay well (1st ed.). Jossey-Bass.

Arnold, C., Huwiler, K., Raulf, B., Tanner, H., \& Wicki, T. (2008). Pflegefamilien- und Heimplatzierungen: Eine empirische Studie über den Hilfeprozess und die Partizipation von Eltern und Kindern [Foster family and home placements: An empirical study on the care process and the participation of parents and children]. Somedia Buchverlag.

Arsenault, V. (2015). Resistance to the Canadian Truth and Reconciliation Commission [Working paper]. swisspeace.

Atteslander, P. (2010). Methoden der empirischen Sozialforschung (12., durchgesehene Auflage) [Methods of empirical social research (12th ed., revised)]. Erich Schmidt Verlag.

Bergold, J., \& Thomas, S. (2010). Partizipative Forschung [Participatory research]. In G. Mey \& K. Mruck (Eds.), Handbuch Qualitative Forschung in der Psychologie [Handbook of qualitative research in psychology] (pp. 333-344). VS Verlag für Sozialwissenschaften.

Black, M. C., \& Black, R. S. (2007). A public health perspective on "The ethics of asking and not asking about abuse”. American Psychologist, 62(4), 328-329. doi:10.1037/0003$\underline{066 \times 62.4 .328}$

Bombach, C., Gabriel, T., Galle, S., \& Keller, S. (2018). Die "neuen Praktikanten”Perspektiven auf sich verändernde Beziehungsformen im Heim der 1960er- und 1970er-Jahre [The "new interns" - Prospects for changing the types of relationships in the home of the 1960s and 1970s]. In G. Hauss, T. Gabriel, \& M. Lengwiler (Eds.), Fremdplatziert. Heimerziehung in der Schweiz, 1940-1990 [Foreign placed: Home education in Switzerland, 1940-1990] (pp. 219-243). Chronos. 
International Journal of Child, Youth and Family Studies (2020) 11(4): 96-120

Bombach, C., Gabriel, T., \& Keller, S. (2018a). "Die wussten einfach, woher ich komme"Staatliche Eingriffe und ihre Auswirkungen auf das Leben ehemaliger Heimkinder ["They just knew where I came from" - State interventions and their effects on the lives of former home children]. In G. Hauss, T. Gabriel, \& M. Lengwiler (Eds.), Fremdplatziert. Heimerziehung in der Schweiz, 1940-1990 [Foreign placed: Home education in Switzerland, 1940-1990] (pp. 117-137). Chronos.

Bombach, C., Gabriel, T., \& Keller, S. (2018b). "Legitimieren” und "integrieren"-Die Auswirkungen von Heimerfahrungen auf den weiteren Lebensverlauf ["Legitimize"and "integrate" - The effects of home experiences on the rest of your life.. In G. Hauss, T. Gabriel, \& M. Lengwiler (Eds.), Fremdplatziert. Heimerziehung in der Schweiz, 1940-1990 [Foreign placed: Home education in Switzerland, 1940-1990] (pp. 253-272). Chronos.

Bombach, C., Gabriel, T., \& Keller, S. (2018c). Vulnerabilität und Anerkennung. Erzählte Biografie nach Heimplatzierungen zwischen 1950 und 1990 [Vulnerability and recognition. Narrated biography after home placement between 1950 and 1990]. In B. Ziegler, G. Hauss, \& M. Lengwiler (Eds.), Zwischen Erinnerung und Aufarbeitung. Fürsorgerische Zwangsmassnahmen an Minderjährigen in der Schweiz im 20. Jahrhundert [Between memory and reappraisal: Compulsory care measures for minors in Switzerland in the 20th century] (pp. 83-109). Chronos.

Bombach, C., Gabriel, T., \& Keller, S. (2018d). Zum Verschwinden und Entwerten der Persönlichkeit, der eigenen Bedürfnisse und individuellen Erfahrungen [To disappear and devalue your personality, your own needs and individual experiences] (Stellungnahme zum Thema: Forschungserkenntnisse zur Anzahl Solidaritätsbeitragsgesuche von Opfern fürsorgerischer Zwangsmassnahmen [Opinion on the topic: Research findings on the number of applications for solidarity contributions by victims of preventive coercive measures]). Zürcher Hochschule für Angewandte Wissenschaften (ZHAW). https://www.newsd.admin.ch/newsd/message/attachments/51032.pdf

Bombach, C., Gabriel, T., \& Keller, S. (2020). Lebensverläufe nach Heimerziehung. Wie ein ermüdendes Erkämpfen individueller Handlungsspielräume Biografien prägt [Life history after home education: How a tiring fight for individual room for maneuver shapes biographies]. In S. Göbel, U. Karl, M. Lunz, U. Peters, \& M. Zeller (Eds.), Wege junger Menschen aus Heimen und Pflegefamilien. Agency in schwierigen Übergängen [Paths of young people from homes and foster families. Agency in difficult transitions] (pp. 275-290). Beltz Juventa.

Bombach, C., Gabriel, T., Keller, S., Ramsauer, N., \& Marx, A. S. (2017). Zusammen alleine: Alltag in Winterthurer Kinder- und Jugendheimen 1950-1990 [Alone together: Everyday life in children's and youth homes in Winterthur 1950-1990]. Chronos. 
International Journal of Child, Youth and Family Studies (2020) 11(4): 96-120

Botschaft zur Volksinitiative, "Wiedergutmachung für Verdingkinder und Opfer fürsorgerischer Zwangsmassnahmen (Wiedergutmachungsinitiative)" und zum indirekten Gegenvorschlag [Message on the popular initiative "Reparation for contract children and victims of coercive preventive measures (reparations initiative)" and the indirect counter-proposal] (Bundesgesetz über die Aufarbeitung der fürsorgerischen Zwangsmassnahmen und Fremdplatzierungen vor 1981 [Federal act on the processing of the preventive coercive measures and third party placements before 1981]) 15.082 (2015).

Bowlby, J. (1951). Maternal care and mental health. World Health Organization Monograph Series, 2, 179.

Brabin, P. J., \& Berah, E. F. (1995). Dredging up past traumas: Harmful or helpful? Psychiatry, Psychology and Law, 2(2), 165-171. doi:10.1080/13218719509524863

Bundesgesetz über die Aufarbeitung der fürsorgerischen Zwangsmassnahmen und Fremdplatzierungen vor 1981 [Federal law on the processing of preventive coercive measures and third party placements before 1981] (AFZFG), 211.223.13 (2017).

Businger, S., \& Ramsauer, N. (2019). “Genügend goldene Freiheit gehabt” Heimplatzierungen von Kindern und Jugendlichen im Kanton Zürich, 1950-1990 ["Enough golden freedom”: Placements of children and adolescents in the canton of Zurich, 1950-1990]. Chronos.

Charters, E. (2003). The use of think-aloud methods in qualitative research: An introduction to think-aloud methods. Brock Education Journal, 12(2), 68-82. https://journals.library.brocku.ca/brocked/index.php/home/article/view/38

Chiapparini, E. (Ed.). (2016). The service user as a partner in social work projects and education: Concepts and evaluations of courses with a gap-mending approach in Europe. Barbara Budrich.

Dyregrov, K. M., Dieserud, G., Hjelmeland, H. M., Straiton, M., Rasmussen, M. L., Knizek, B. L., \& Leenaars, A. A. (2011). Meaning-Making through psychological autopsy interviews: The value of participating in qualitative research for those bereaved by suicide. Death Studies, 35(8), 685-710. doi:10.1080/07481187.2011.553310

Flick, U. (2014). An introduction to qualitative research (5th ed.). Sage.

Freyd, J. J. (1996). Betrayal trauma: The logic of forgetting childhood abuse. Harvard University Press.

Furrer, M., Heiniger, K., Huonker, T., Jenzer, S., \& Praz, A.-F. (2014). Fürsorge und Zwang: Fremdplatzierung von Kindern und Jugendlichen in der Schweiz 1850-1980 [Care and coercion: Placement of children and adolescents in Switzerland 1850-1980; Vol. 36]. Schwabe. 
International Journal of Child, Youth and Family Studies (2020) 11(4): 96-120

Galle, S. (2016). Kindswegnahmen: Das "Hilfswerk für die Kinder der Landstrasse” der Stiftung Pro Juventute im Kontext der schweizerischen Jugendfürsorge [Child removals: The Pro Juventute Foundation's "Relief society for rural children" in the context of Swiss youth welfare]. Chronos.

Hafner, U. (2011). Heimkinder: eine Geschichte des Aufwachsens in der Anstalt [Home children: A story of growing up in an institution]. Hier und Jetzt.

Hauss, G. (2018). Geschichten und Gegengeschichten. Die Hochschule als Ort einer reflexiven Historiografie [Stories and counter-stories: The university as a place for reflective historiography]. In B. Ziegler, G. Hauss, \& M. Lengwiler (Eds.), Zwischen Erinnerung und Aufarbeitung. Fürsorgerische Zwangsmassnahmen an Minderjährigen in der Schweiz eim 20. Jahrhundert [Between memory and reappraisal: Compulsory care measures for minors in Switzerland in the 20th century] (pp. 213-226). Chronos.

Hauss, G., Gabriel, T., \& Lengwiler, M. (Eds.). (2018). Fremdplatziert. Heimerziehugn in der Schweiz, 1940-1990 [Foreign placed: Home education in Switzerland, 1940-1990]. Chronos.

Jorm, A. F., Kelly, C. M., \& Morgan, A. J. (2007). Participant distress in psychiatric research: A systematic review. Psychological Medicine, 37(7), 917-926.

doi:10.1017/S0033291706009779

Lannen, P., Sticca, F., Bombach, C., Sand, H., Ruiz Gallego, I., Simoni, H., \& Jenni, O. G. (in press). Developmental trajectories of individuals placed in infant care institutions - A 60-year follow-up [Research topic: Longitudinal aging research: cognition, behavior and neuroscience]. Frontiers in Human Neuroscience.

Lengwiler, M. (2018). Aufarbeitung und Entschädigung traumatisierender Fremdplatzierungen. Die Schweiz im internationalen Vergleich [Processing and compensation for traumatized third-party placements: Switzerland in international comparison]. In B. Ziegler, G. Hauss, \& M. Lengwiler (Eds.), Zwischen Erinnerung und Aufarbeitung. Fürsorgerische Zwangsmassnahmen an Minderjährigen in der Schweiz im 20. Jahrhundert [Between memory and reappraisal: Compulsory care measures for minors in Switzerland in the 20th century] (pp. 159-176). Verlag.

Lengwiler, M., \& Praz, A.-F. (2018). Kinder- und Jugendfürsorge in der Schweiz. Entstehung, Implementierung und Entwicklung (1900-1980) \{Child and youth welfare in Switzerland: Origin, implementation, and development (1900-1980]. In G. Hauss, T. Gabriel, \& M. Lengwiler (Eds.), Fremdplatziert. Heimerziehung in der Schweiz, 1940-1990 [Foreign placed: Home education in Switzerland, 1940-1990] (pp. 29-52). Chronos.

Masten, A. S., \& Obradović, J. (2006). Competence and resilience in development. Annals of the New York Academy of Sciences, 1094(1), 13-27. doi:10.1196/annals.1376.003 
International Journal of Child, Youth and Family Studies (2020) 11(4): 96-120

Mayring, P. (2015). Qualitative Inhaltsanalyse. Grundlagen und Techniken (12. überarbeitete Auflage) [Qualitative content analysis: Basics and techniques (12th ed., revised]. Beltz Juventa.

Meierhofer, M., \& Hüttenmoser, M. (1975). Die spätere Entwicklung von Kindern, welche ihre erste Lebenszeit in Säuglings- und Kinderheimen verbracht hatten. Untersuchungsbericht zuhanden des Schweizerischen Nationalfonds für wissenschaftliche Forschung [The later development of children who had spent their early life in care homes: Investigative report to the Swiss National Science Foundation]. Archiv Marie Meierhofer Institut.

Meierhofer, M., \& Keller, W. (1974). Frustration im frühen Kindesalter (3. Aufl.) [Frustration in early childhood (3rd. ed.)]. Hans Huber.

Omerov, P., Steineck, G., Dyregrov, K., Runeson, B., \& Nyberg, U. (2014). The ethics of doing nothing. Suicide-bereavement and research: Ethical and methodological considerations. Psychological Medicine, 44(16), 3409-3420. doi:10.1017/S0033291713001670

Ramsauer, N. (2000). "Verwahrlost” Kindswegnahmen und die Entstehung der Jugendfürsorge im schweizerischen Sozialstaat 1900-1945 ["Neglected" children and the emergence of childcare in the Swiss welfare state 1900-1945]. Chronos.

Ryffel, G., \& Simoni, H. (2016). Forschungsdokumentation zum Projekt Lebensverläufe nach strukturell bedingter Frustration der frühesten Entwicklungsbedürfnisse unter dem Aspekt der Resilienz. Retrospektive Teilstudie des Projektes Leben mit Brüchen und Verlusten in der frühen Beziehungsumwelt [Research documentation on the project "Life courses after structural frustration of the earliest development needs under the aspect of resilience": Retrospective partial study of the project "Living with breaks and losses in the early relationship environment”]. Marie Meierhofer Institut für das Kind.

Schoch, J. (Ed.). (1989). Aufwachsen ohne Eltern. Verdingkinder, Heimkinder, Pflegekinder, Windenkinder. Zur außerfamiliären Erziehung in der deutschsprachigen Schweiz. [Growing up without parents. Contract children, home children, foster children, wind children. For nonfamily education in German-speaking Switzerland]. Chronos.

Seglias, L. (2018). Fürsorgerische Zwangsmassnahmen und Fremdplatzierungen im Zeichen gesellschaftspolitischer Aufarbeitung [Compulsory social measures and placements on behalf of sociopolitical reconciliation]. In B. Ziegler, G. Hauss, \& M. Lengwiler (Eds.), Zwischen Erinnerung und Aufarbeitung. Fürsorgerische Zwangsmassnahmen an Minderjährigen in der Schweiz im 20. Jahrhundert [Between memory and reappraisal: Compulsory care measures for minors in Switzerland in the 20th century] (pp. 21-31). Chronos.

Sinclair, R. (2007). Identity lost and found: Lessons from the Sixties Scoop. First Peoples Child and Family Review, 3(1), 65-82. 
International Journal of Child, Youth and Family Studies (2020) 11(4): 96-120

Sommaruga, S. (2013, April 11). Nichts ist kostbarer als die menschliche Würde [Nothing is more precious than human dignity]. Rede von Bundesrätin, Gedenkanlass für ehemalige Verdingkinder und Opfer von fürsorgerischen Zwangsmassnahmen [Speech by the Federal Councilor, Memorial Event for Former Contract Children and Victims of Coercive Measures], Bern, Switzerland.

Spitz, R. (1945). Hospitalism: An inquiry into the genesis of psychiatric conditions in early childhood. The Psychoanalytic Study of the Child, 1, 53-73.

doi:10.1080/00797308.1945.11823126

Steiner, C. M., \& Perry, P. (1999). Achieving emotional literacy: A personal program to increase your emotional intelligence. Bloomsbury.

Unabhängige Expertenkommission (Ed.). (2019). Organisierte Willkür. Administrative Versorgungen in der Schweiz 1930-1981 (Schlussbericht: Vol. 10A) [Organized arbitrariness: Administrative care in Switzerland 1930-1981 (Final report, Vol. 10a)]. Unabhängige Expertenkommission Administrative Versorgung, Chronos.

Unabhängige Expertenkommission (UEK) Fürsorgerische Zwangsmassnahmen. (2019). “(...) Die Stärke des Volkes sich misst am Wohl des Schwachen (...)” Empfehlungen der Unabhängigen Expertenkommission (UEK) Administrative Versorgung [“(...) the strength of the people is measured by the well-being of the weak (...)": Recommendations of the Independent Expert Commission (UEK) Administrative Care]. https://www.uekadministrative-versorgungen.ch/resources/Empfehlungen_UEK_DE_201909021.pdf

Watt, D. F., \& Panksepp, J. (2016). Psychology and neurobiology of empathy. Nova Science.

Wehrle, F. M., Caflisch, J. A., Eichelberger, D., Kakebeeke, T. H., Latal, B., \& Jenni, O. G. (in press). Health and development across the lifespan - The Zurich longitudinal studies. [Research topic: Longitudinal aging research: Cognition, behavior and neuroscience]. Frontiers in Human Neuroscience.

Werner, E. E. (2013). What can we learn about resilience from large-scale longitudinal studies? In S. Goldstein \& R. B. Brooks (Eds.), Handbook of resilience in children (pp. 87-102). Springer. doi:10.1007/978-1-4614-3661-4_6 
Wigger, A. (2018). Nothilfe, Entschädigung, Entschuldigung im Kontext von fürsorgerischen Zwangsmassnahmen und Fremdplatzierung im Zeitraum von 1981-Das Modell des "Runden Tisches". Ein Erfahrungsbericht [Emergency relief, compensation, apology in the context of coercive measures and third party placement in the 1981 period — the "Round Table" model: An experience report]. In B. Ziegler, G. Hauss, \& M. Lengwiler (Eds.), Zwischen Erinnerung und Aufarbeitung. Fürsorgerische Zwangsmassnahmen an Minderjährigen in der Schweiz im 20. Jahrhundert [Between memory and reappraisal: Compulsory care measures for minors in Switzerland in the 20th century] (pp. 141-158). Chronos.

Ziegler, B. (2018). Einleitung [Introduction]. In B. Ziegler, G. Hauss, \& M. Lengwiler (Eds.), Zwischen Erinnerung und Aufarbeitung. Fürsorgerische Zwangsmassnahmen an Minderjährigen in der Schweiz im 20. Jahrhundert [Between memory and reappraisal: Compulsory care measures for minors in Switzerland in the 20th century] (pp. 71-72). Chronos.

Ziegler, B., Hauss, G., \& Lengwiler, M. (2018). Einleitung [Introduction]. In B. Ziegler, G. Hauss, \& M. Lengwiler (Eds.), Zwischen Erinnerung und Aufarbeitung. Fürsorgerische Zwangsmassnahmen an Minderjährigen in der Schweiz im 20. Jahrhundert [Between memory and reappraisal: Compulsory care measures for minors in Switzerland in the 20th century] (pp. 9-16). Chronos. 